Arq. Bras. Med. Vet. Zootec., v.73, n.3, p.752-756, 2021

\title{
Communication
}

[Comunicação]

\section{Does a single application of contraceptive cause pathological changes in bitches?}

[Uma única aplicação de anticoncepcional causa alterações patológicas em cadelas?]

\author{
P.L. Sala ${ }^{1}$, M.M.Q. Assis ${ }^{2}$, R.C.L. Ribeiro ${ }^{1}$, T.C. $S a^{1}$, A.G.P. Rocha ${ }^{1}$, \\ L.T. Maia ${ }^{2}$, T.P. Silva ${ }^{3}$, M.S. Trentim ${ }^{1}$, A.M. Quessada ${ }^{4 *}$ \\ ${ }^{1}$ Veterinário autônomo \\ ${ }^{2}$ Aluno de pós-graduação - Universidade Paranaense - Umuarama, PR \\ ${ }^{3}$ Aluna de graduação -Universidade Paranaense - Umuarama, PR \\ ${ }^{4}$ Universidade Paranaense - Umuarama, PR.
}

The widely used form of reproductive control in domestic animals is pharmacological, mainly through the administration of progestins (Romagnoli, 2002), This form of contraception is characterized by veterinary contraceptives found in the form of injectable solutions or steroid hormone tablets that act by delaying or suppressing the sexual acceptance phase (Vigo et al., 2011). Studies have shown a high frequency of complications observed after the use of progestins in dogs and cats, especially when applied in phases other than anestrus. The administration of these drugs leads to problems such as pyometra, fetal maceration, endometrial hyperplasia, mammary hyperplasia, mammary tumors (Araújo et al., 2017), skin reactions at the application site, insulin resistance, among others (Romagnoli, 2002).

In view of the above, the present study aimed to evaluate the effects of administration in a single dose of progestins in healthy canine females who had never received such drugs. The project that originated this article was approved by the animal ethics committee of the Paranaense University under protocol number 34626/2018. Veterinary stores were visited and in these stores twenty female dog owners who acquired contraceptives to apply to their female dogs were approached. Thus, there was no interference from researchers in the acquisition of contraceptives. Only owners who were buying the product for the first time were selected. The data of the bitches selected for the project are listed in Table 1. Before the contraceptive application, all female dogs were clinically examined. Anamnesis, physical examination, blood count, biochemical tests (total proteins, calcium, urea, creatinine and alanine aminotransferase), abdominal ultrasound and vaginal cytology were performed. Only bitches that did not show pathological changes in all exams were selected.

The female dogs were submitted to the contraceptive administration acquired by the owner (Table 1). All drugs were injectable and were applied subcutaneously to the right lateral abdominal region. Ninety days after the administration of contraceptives, all dogs were submitted to ovariohysterectomy by conventional method (Stone, 2007). The ovaries were identified in relation to the side and sectioned longitudinally. The uterine horns were opened in the longitudinal direction and identified in relation to the side. The pieces were then processed for histopathological exams. In the statistical analysis of the data obtained, a descriptive analysis of the data was performed by determining the absolute and relative frequency $(\%)$. For continuous variables, descriptive statistics were performed by determining the mean and standard deviation. The cross-reference table for the basal cytology and histopathological results used contraceptive and the result of histopathological analysis was performed. The results of the presence of animals with changes in histopathological examination (mild and severe cystic endometrial hyperplasia) for the phases of proestrus and estrus were compared using Fisher's Exact test.

Recebido em 2 de fevereiro de 2021

Aceito em 5 de abril de 2021

*Autor para Correspondência (corresponding author)

E-mail: mariaquessada@prof.unipar.br 
Table 1. Data referring to the 20 female dogs included in a study about contraceptives

\begin{tabular}{lccccc}
\hline \multicolumn{1}{c}{ Breed } & $\begin{array}{c}\text { Age } \\
\text { (month) }\end{array}$ & $\begin{array}{c}\text { Weight } \\
\mathrm{kg}\end{array}$ & Drug & $\begin{array}{c}\text { Cycle estrus phase } \\
\text { by vaginal cytology }\end{array}$ & $\begin{array}{c}\text { Uterine } \\
\text { histopathological } \\
\text { classification }\end{array}$ \\
\hline German Shepherd & 6 & 20 & Anticion* & Anestrus & Normal \\
Chow Chow & 11 & 18,8 & Inibidex** & Estrus & MCEH \\
Mixed breed & 26 & 8,55 & Anticion & Estrus & MCEH \\
Mixed breed & 24 & 9,2 & Inibidex & Estrus & MCEH \\
Mixed breed & 60 & 5 & Inibidex & Proestro & SCEH \\
Mixed breed & 24 & 7,8 & Inibidex & Proestrus & NCC \\
Mixed breed & 12 & 6,75 & Inibidex & Diestrus & NCC \\
Mixed breed & 60 & 5 & Inibidex & Estrus & SCEH \\
Boxer & 48 & 29 & Inibidex & Estrus & MCEH \\
Mixed breed & 6 & 9 & Inibidex & Diestrus & NCC \\
Shih tzu & 64 & 4,4 & Anticion & Diestrus & NHCGE \\
Mixed breed & 24 & 6,4 & Inibidex & Proestrus & NHCEG \\
Daschund & 29 & 6,3 & Anticion & Proestrus & NHCEG \\
Mixed breed & 24 & 7,6 & Anticion & Proestrus & NCC \\
Shit Tzu & 11 & 5,3 & Inibidex & Proestrus & SCEH \\
Daschund & 36 & 7 & Anticion & Proestrus & NHCGE \\
Daschund & 55 & 6,3 & Anticion & Diestrus & NHCGE \\
Mixed breed & 8 & 6,7 & Anticion & Diestrus & NCC \\
Mixed breed & 8 & 6 & Inibidex & Proestrus & NCC \\
Pitt bull & 108 & 29 & Anticion & Proestrus & NCC \\
\hline Antion & & & & & \\
\hline
\end{tabular}

* Anticion (2018) (Medroxyprogesterone acetate, UCBVET, Brazil)

**Inibidex (2018) (Medroxyprogesterone acetate, LAVIZOO, Brazil)

MCEH: Mild Cystic Endometrial Hyperplasia

SCEH: Severe Cystic Endometrial Hyperplasia

NCC: Normal, with circulatory changes (edema and hemorrhage)

NHCGE: Normal with hyperplastic changes in the endometrial gland

For the red blood cells, leukocytes, platelets, urea, creatinine and alanine aminotransferase (ALT) variables over time (basal, 30 days and 90 days) the results were compared using Repeated Measurement Variance Analysis. The Mauchly sphericity test was used to assess the sphericity of the data. When the sphericity hypothesis was violated $(\mathrm{P}<0.05)$ the degrees of freedom were corrected using Greenhouse and Geisser's estimates of sphericity. The analyzes were performed using the statistic program IBM SPSS v. 21.0. For all tests, a significance level of 5\% was considered. Only healthy bitches were selected for the project to prevent the application of the contraceptive from worsening any present disease. The use of contraceptives in dogs can only be considered safe if the animal is healthy at the time of administration (Romagnoli, 2006; Maenhoudt et al., 2018). Among the diseases that can be aggravated by the use of contraceptives are diabetes, lesions or tumors in the mammary glands and cystic endometrial hyperplasia (Romagnoli, 2006).
When the bitches were examined again at thirty days, no changes in blood counts and ultrasound examinations were observed. However, on physical examination, 12 female dogs $(60 \%$; $12 / 20$ ) had mammary hyperplasia (Figure 1). This change is due to the action of the progestin on the mammary gland. Progesterone induces important changes in the mammary gland, creating a highly proliferative environment inside the mammary gland (Martins and Lopes, 2005). The presence of mammary hyperplasia detected in the bitches in the study may be a predisposing factor for the appearance of mammary tumors. There is a report of an association between mammary tumors in female dogs and administration of contraceptives (Honório et al., 2017). It was not possible to perform histopathology of the mammary glands because the owners did not authorize the biopsy it, which is a limiting factor of the present study.

In 18 bitches $(90 \% ; 18 / 20)$, the uterus presented macroscopic changes compatible with cystic endometrial hyperplasia (CEH) (Figure 2A). Of 


\section{Sala et al.}

these bitches that presented $\mathrm{CEH}$, five presented purulent secretion in the uterus $(27.77 \% ; 5 / 18)$ in association with CEH (Figure 2B). The presence of pus associated with $\mathrm{CEH}$ characterizes pyometra (Kempisty et al., 2013). Therefore, five healthy bitches presented pyometra with a single application of contraceptives. Upon microscopic examination, only one female dog had completely normal uterine tissue (Figure 3A), according to the classification proposed in the literature (Monteiro et al., 2009). This bitch was in anestrus. The package inserts of the contraceptives used in the present study inform that the drug should be administered in the anestrus to minimize side effects (Anticion, no date; Inibidex, no date). However, the recognition of the bitch estrous cycle phase can only be performed by means of vaginal cytology, an examination restricted to the veterinarian (Silva, 2016).
On microscopic examination, 19 female dogs $(95 \% ; 19 / 20)$ presented uterine changes that ranged from circulatory changes (edema and hemorrhage) to severe cystic endometrial hyperplasia (Figure 3) (Table 1). Probably mild uterine changes (Figure 3 ) would tend to regress, and the animal could be normal in the next estrous cycle. The progesterone concentration in dogs with $\mathrm{CEH}$ is comparable to that observed during the diestrus of normal canine females (Chen et al., 2001). However, three bitches presented severe CEH (Figure 3 B,C,D.) (Table 1), according to the literature classification (Monteiro et al., 2009). Thus, it can be inferred that the application of the contraceptive promoted such changes, since only healthy bitches were selected for the study.
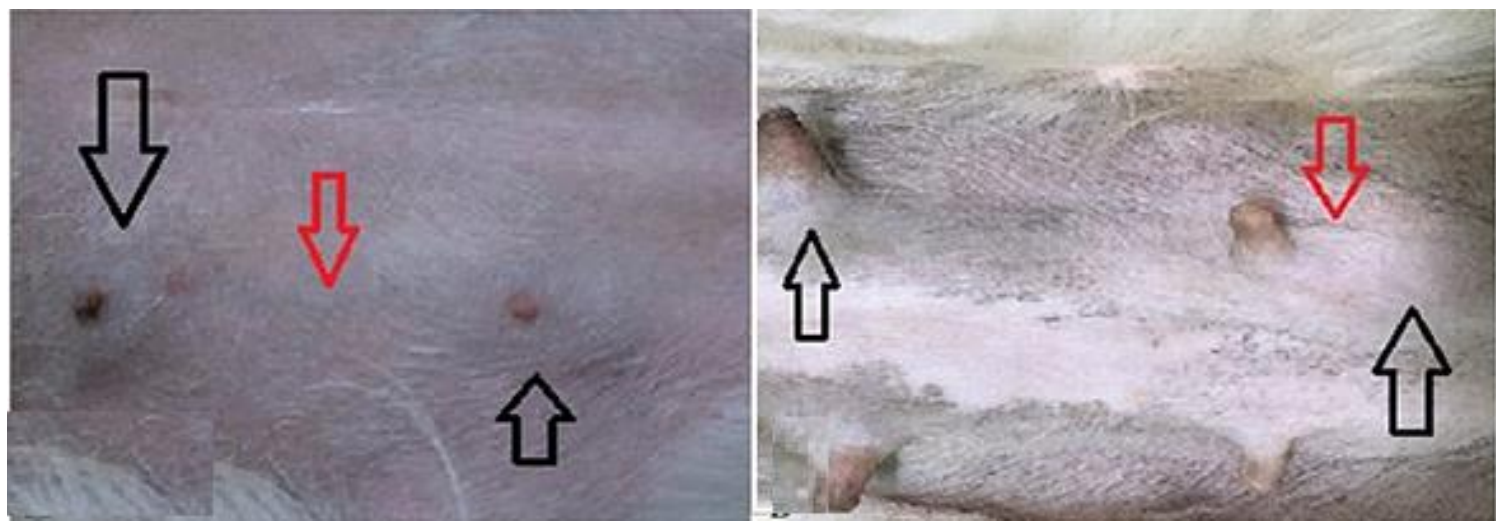

Figure 1. Mammary chain of bitches 30 days after being submitted to the application of injectable contraceptives. Black arrows: hypertrophied mammary glands. Red arrows: accentuated vascularization.

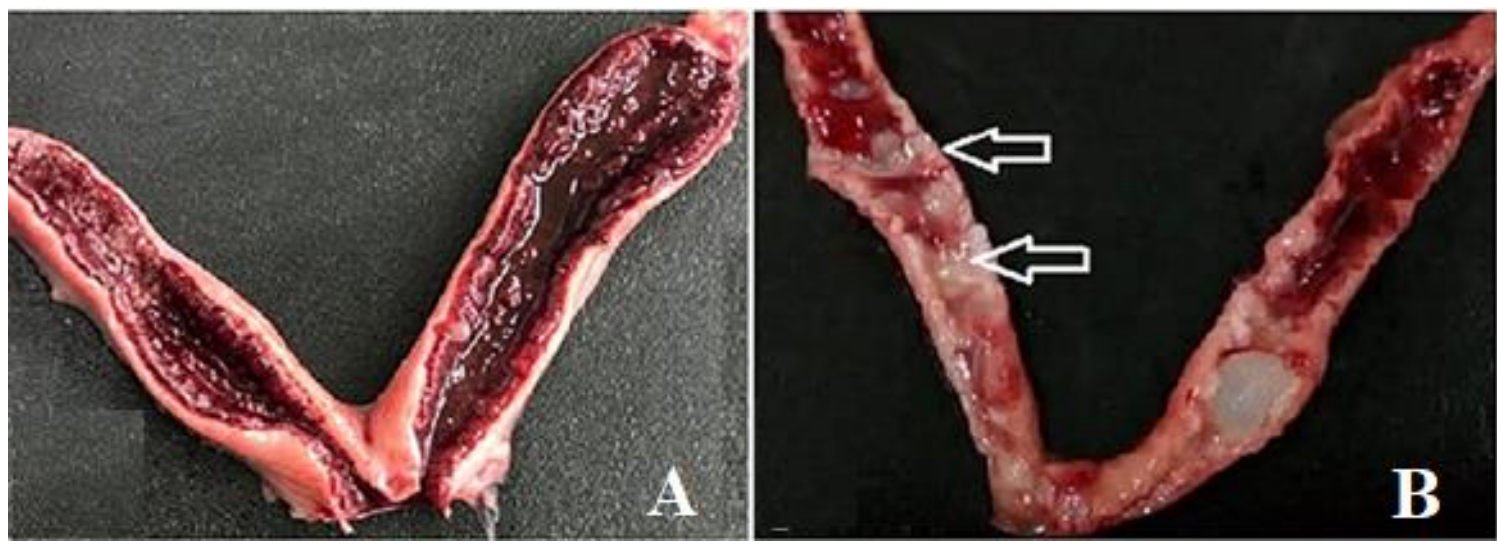

Figure 2. Uterus of bitches, ninety days after application of injectable contraceptive. A: Hemorrhagic and cystic areas are observed. B: There is the presence of purulent secretion (arrows). 

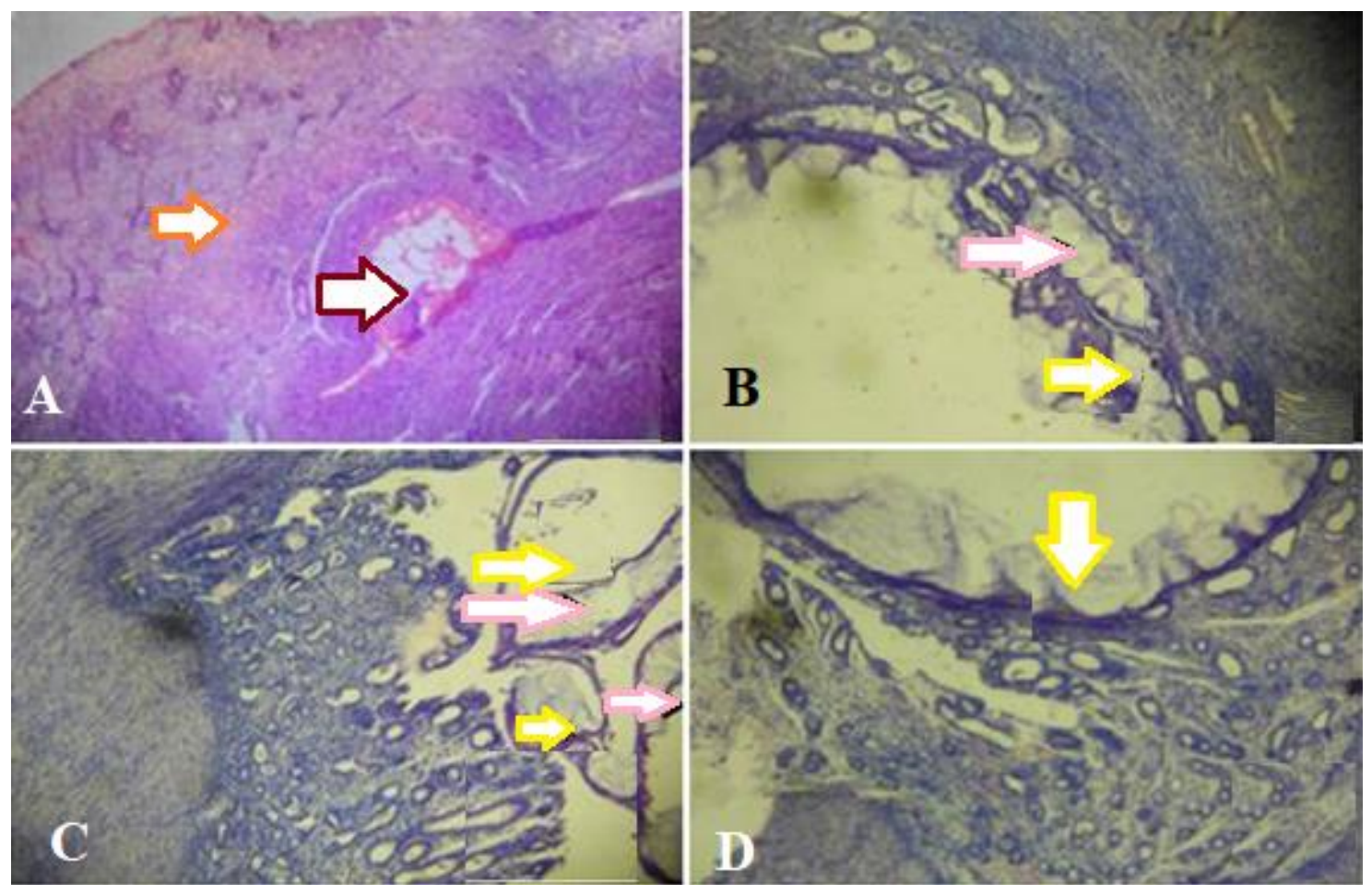

Figure 3. Histopathological section of bitch uterus, ninety days after the application of injectable contraceptives. A: The appearance is normal but shows circulatory changes (edema and hemorrhage). Observe vessel congestion (black/white arrow) and diffuse hemorrhage in the myometrium and endometrium (red/white arrow). B, C, D: Severe cystic endometrial hyperplasia. Cystic glands: yellow/white arrow. Content in the light of the glands: pink/white arrow). Photos captured in 4x / 0.10 lens.

Despite these results, statistical analyzes by Fischer's exact test comparing parameters two by two did not show statistical significance. It is likely that the absence of statistical significance is due to the small sample size compared to the various parameters analyzed. The administration of synthetic progestogens in bitches increases the number of estrogen and progesterone receptors in the endometrial glands, causing thickening of the endometrium. Such thickening is due to labyrinthic-like proliferations of surface epithelial cells, massive secretion, and cystic dilatation of endometrial gland lumina all of which are characteristics of cystic endometrial hyperplasia (De Bosschere et al., 2002). In this way, A single application of injectable contraceptives (package insert dose) in bitches was able to cause pathological changes in the reproductive system of these animals, mainly cystic endometrial hyperplasia.

Keywords: canine, contraceptives, cystic endometrial hyperplasia, progestins

\section{RESUMO}

O presente trabalho objetivou avaliar os efeitos da administração em dose única de progestágenos em fêmeas caninas hígidas, as quais nunca haviam recebido tais fármacos. Foram selecionadas 20 cadelas, que foram examinadas clinicamente e por meio de exames complementares. Nessas cadelas, foi aplicado medroxiprogesterona por via subcutânea. Noventa dias após, as fêmeas foram esterilizadas cirurgicamente, sendo os tecidos reprodutivos encaminhados para histopatologia. Foi possível verificar que, aos 30 dias, 12 animais (60\%) apresentaram hiperplasia mamária. Aos 90 dias, 18 animais (90\%) apresentavam sinais de hiperplasia endometrial cística, tendo cinco $(27,77 \%)$ destes animais apresentado conteúdo purulento no lúmen uterino. No exame microscópico, apenas uma fêmea não demonstrou alterações patológicas, sendo a única que recebeu o contraceptivo na fase correta (anestro). As demais fêmeas apresentaram alterações que variaram entre alterações circulatórias a hiperplasia endometrial 


\section{Sala et al.}

cística grave. Assim, foi possível concluir que uma única aplicação de anticoncepcional em fêmeas hígidas pode causar complicações leves a graves.

Palavras-chave: canina, contraceptivos, hiperplasia endometrial cística, progestágenos

\section{ACKNOWLEDGEMENTS}

We thank the Paranaense University (UNIPAR) for funding the research. To CAPES for the granting of a doctoral scholarship to the main author. The authors have no conflict of interests.

\section{REFERENCES}

Anticion S/D. Anticion. Available in: http://www.ucbvet.com/produto/14/6/anticion. Accessed in: 30 Sept. 2020.

ARAÚJO, B.M.; FERNANDES, T.H.T.; BARAÚNA JÚNIOR D. et al. Clinical and epidemiological study in dogs with thoracolumbar vertebrae fractures and luxations. Pesqui. Vet. Bras., v.37, p.866-870, 2017.

CHEN, Y.M.; WRIGHT, P.J.; LEE, C.S. A model for the study of cystic endometrial hyperplasia in bitches. $J$ Reprod fert, v. 57, sup 1, p. 407-414, 2001.

DE BOSSCHERE, H.; DUCATELLE, R.; TSHAMALA, M.; CORYN, M. Changes in sex homones receptors during administration of progesterone to prevent estrus in the bitch. Theriogenology, v.58, p.1209-1217, 2002.

HONÓRIO, T.G.A.F.; FONSECA, A.P.B.; ARAÚJO, E.K.D. et al. Implicações patológicas após o uso de anticoncepcional, em cadelas situadas em Teresina - PI. PubVet. v.11, p.176180, 2017. Inibidex. S/D. Available in: https://www.vetsmart.com.br/cg/produto/1803/in ibidex. Accessed in: 18 Sept. 2020.

KEMPISTY, B.; BUKOWSKA, D.; WOŹNA, M..; PIOTROWSKA, H.; JACKOWSKA, M..; ZURAW, A..; CIESIÓŁKA, S.; ANTOSIK, P.; MARYNIAK, H.; OCIEPA, E.; POROWSKI, S.; BRUSSOW, K.P.; JASKOWSKI, J.; NOWICKI, M. Endometritis and pyometra in bitches: a review. Vet. Med., v.58, p.289-297, 2013.
MAENHOUDT, C.; SANTOS, N.R.; FONTBONNE, A. Manipulation of the oestrous cycle of the bitch-what works... for now. Reprod. Domest. Anim., v.53, p.44-52, 2018.

MARTINS, L.R.; LOPES, M.D. Pseudociese canina. Rev. Bras. Reprod. Anim, v.29, n.3/4, p.137-141, 2005.

MONTEIRO, C.M.R.; PERRI, S.H.V.; CARVALHO, R.G.; KOIVISTO, M.B. Histologia e morfometria em cornos uterinos de cadelas nulíparas, multíparas e tratadas com contraceptivos. Pesqui. Vet. Bras., v. 29, p.847$851,2009$.

ROMAGNOLI, S. Clinical use of hormones in the control of reproduction in bitches and queens. In: VETERINARY SCIENCES CONGRESS, 2002, Oeiras. Proceedings... Oeiras, Portugal: WSAVA, 2002. p.162-166. Available in: https://citeseerx.ist.psu.edu/viewdoc/download?d oi=10.1.1.617.6718\&rep=rep1\&type=pdf.

Accessed in: 8 Sept. 2020.

ROMAGNOLI, S. Control of reproduction in dogs and cats: use and misuse of hormones. In: WORLD SMALL ANIMAL VETERINARY ASSOCIATION, WORLD CONGRESS, 2006, Czech Republic. Proceedings... Czech Republic: WSAVA, 2006. Available in: https://www.vin.com/apputil/content/defaultadv1 .aspx id $=3859261 \&$ pid=1122. Accessed in: 5 Sept. 2020.

STONE, E.A. Ovário e útero. SLATTER, D.H. (Ed). Manual de cirurgia de pequenos animais. $3^{\mathrm{a}}$ ed. Manole, Barueri, SP: 2007. p. 1487-1502.

SILVA, L.D.M. Controle do ciclo estral em cadelas. Rev. Bras. Reprod. Anim., v.40, p.180187, 2016.

VIGO, F.; LUBIANCA, J.N.; CORLETA, H.E. Progestógenos: farmacologia e uso clínico. Femina, v.39, p.128-137, 2011. 